GEOGRAFIE • ROK 2015 • ČÍSLO 1 • ROČNÍK 120

SLAVOMÍR BUCHER, MIROSLAVA IŠTOKOVÁ

\title{
SELF-GOVERNING REGIONS IN SLOVAKIA: SPATIAL DIFFERENTIATION AND PERCEPTION OF SOCIO-CULTURAL IDENTITY BY LOCAL AND REGIONAL OFFICIALS
}

\begin{abstract}
BUCHER, S., IŠTOKOVÁ, M. (2015): Self-Governing Regions in Slovakia: Spatial Differentiation and Perception of Socio-Cultural Identity by Local and Regional Officials. Geografie, 120, No. 1, pp. 1-25. - This article seeks to contribute to the discussion about the concept of socio-cultural identity in geographical science. Its main aim is to present the concept of local and regional identity, first as a significant source of sustainable national wealth and secondly as an effective tool for regional development in Slovakia. Slovakia consists of several kinds of regions at the sub-national level, represented by historical areas, small ethnographic regions and various administrative units. Their hierarchy derives from their former historical role, current administrative function, and their regional importance. The outputs of this survey indicate regional disparities in the so-called soft factors involved in the development of social identity among Slovakia's self-governing regions. In addition, the article discusses the need for a more comprehensive approach, directly linking ethnographic, geographical and sociological methods.

KEY WORDS: self-governing regions - society - actor/subject in socio-cultural identity perceptions of cultural identity - Slovakia.

This article is part of the following research grant projects: SVV, Charles University in Prague, No. 260199: Socio-geographic and Demographic Conditions in the Development of Regional Disparities and Social Transformations GA ČR P40/12G113: Historical Geography Research Centre.
\end{abstract}

\section{Introduction}

The main aim of this article is to present local and regional identity by responses to carefully selected questions: first, as a significant source of sustainable national wealth and secondly as an effective tool for regional development in Slovakia. The chosen questions seek to identify the endogenous potential of an area and activities connected with pride in being a member of a local and regional community. Awareness of the importance of local and regional identity development helps a local community to identify itself with its space and the local population takes more responsibility for its socio-economic development and a healthy environment within the region. Maintenance and enhancement of local traditions and customs not only encourages promotion of local tourism but also generates feelings of happiness and self-confidence among inhabitants.

An outline of the impact of so-called soft factors in the development of social and cultural identity is presented for the eight self-governing regions of 
Slovakia. This research is centred on statistical analysis of regional identity in Slovakia's self-governing regions based upon empirical data from a survey questionnaire.

The study's focus is on identification of the relationship between the collective identity of representatives of local and regional elected officials and the cultural heritage and socio-cultural potential of a region.

The questions were formulated around the key features of regional identity: performance, tradition, communication, emotional power and organizational values. Each municipality or region has its history, its face - the so-called genius loci. These traditional values constitute the true identity of the locale, often struggling daily against uniformity and homogeneity.

To achieve the main aim - to identify the relationship of representatives of local and regional governments to a specific area and the local identity that forms social and cultural cohesion within the population (the feeling of home) that is an essential element of one's identity - the following research questions were posed:

1. Which differences can be observed when comparing the urban and rural population according to the "intensity" and manifestations of their regional identity?

2. How does the indigenous population (native residents) differ from immigrants (those who reside elsewhere than their birth city) in the "intensity" and manifestations of regional identity?

3. What are the differences among self-governing regions according to the "intensity" and manifestations of regional identity? How important are the role of social, territorial and cultural characteristics within a region?

4. How is the construction of a local and/or regional identity affected by its cultural heritage and the cultural-historical potential of Slovak regions?

This set of questions was chosen taking into account the identification of respondents with knowledge of the cultural heritage and socio-cultural potential of their region. Paasi $(1986,2001,2003,2004)$ and Thrift (1998) declared that development of regional structures, in terms of the establishment of institutions, is preceded by the symbolic formation of a region. A driving force in the process of institutionalization is the regional potential for cultural-historical and ethnographic identity. The fellowship of inhabitants during diverse cultural and social manifestations (events, occasions, holidays etc.) advances the creation and maintenance of local or regional memory and pride. Eventually, what stays in consciousness is the initiative of individuals, the region's (external or self-) image, and its name as well as institutions that diffuse a positive image and awareness through mass media, regional literature and the education system.

\section{Theoretical framework}

The selection of respondents to assess collective identity (urban and rural population, native residents, immigrants) was implemented in accordance with the methodologies of Sweeney (1990), Spilling (1991), Meier-Dallach (1980), Sabel (1992), and Mingione (1994) ${ }^{1}$. It is based on the premise that each person belongs to a certain group without the possibility of choice (e.g. by birth in a 
community) or that a person can become aligned with another community during his/her lifetime (thereby exchanging it for the previous one). In a similar manner, this premise can be applied to the relationship of inhabitants to a particular region. If socio-economic stagnation occurs and native residents do not leave the region, it is possible to assess positive and negative stages of regional development.

The meaning of identity in space also considers the continuous interconnections between the opposing impacts of traditions and innovations, leading to harmony and generational transmission of identity consciousness. The counteracting influences of traditions and innovations cannot be and, of course, are not absolute. In certain regions, especially those with rationally-perceived aspects of tradition (for example, the availability of job opportunities), the instability can cause really strong interference in the harmony between rational and irrational forces (Tangkjaer, Linde-Laursen 2004).

Moreover, people themselves reflect their personal existence (self) among other characteristics (humanity, administrative units, etc.) by their identity. For an individual, identification with a specific place is inevitably searching for, networking and (especially) continuing his/her own historical existence. The multicultural society that emerged in Europe at the beginning of the $20^{\text {th }}$ century has caused more uniformity in life and culture; on the other hand, it is leading to very intense development and interconnection of irrational (especially social) components of the landscape.

Paasi $(1986,2001,2003,2004)^{2}$ argues that the development of regional structures in terms of institutionalization is preceded by a phase of symbolic construction of the region. The driving force of this process represents the cultural-historical and ethnographic potential of the region. The fellowship of inhabitants in various cultural and social manifestations contributes to formation and maintenance of pride and respect for their region. A key role in regional institutionalization itself is played by the initiative of individuals, the (external and internal) image of the region, its name and also the establishment of institutions that subsequently spread the awareness and positive image through mass media, regional literature and the education system.

The positive alternative lies in the use of endogenous local factors, including regional history and traditions as the (last but not least) impetus for territorial stabilization. Social and cultural factors, as well as the diffusion of knowledge, stimulate a multiplier effect associated with innovations (Bund) and implementation of new technologies resulting in a favourable internal and external image - positive regional development.

The negative alternative assumes passive acceptance of the current situation without any option to emigrate, primarily because of strong emotional and cultural ties to a region. However, if bonds to a certain place persist only on the basis of identification with tradition (Gemeinschaft), the region cannot face new challenges. Such a situation usually results in the "lock-in" phenomenon,

1 For more information about methodology: Agnew (1989); Appadurai (1996); Cohen, Kliot (1992).

2 For more details about regional or collective identity construction: Maier, Dallach (1980); Eisenstadt, Giesen (1995); Eriksson (2008). 
stagnation of the economy, reduction of integral social and cultural links and finally in a neutral or negative external image - negative regional development.

The already mentioned descriptions of positive or negative regional development should be related to the collective identity of urban dwellers or the rural population. In the latter case, there is a higher assumption of strong emotional ties to place.

It is presumed that the collective identity of an urban population and immigrants to an area have a lower rate of identification with place than native residents and a rural population. If a crisis affects the population without strong emotional ties to its place of residence and considering potential emigration, two alternatives of future regional development may occur.

The positive alternative deals with mutual cooperation between city quarters and rural communities as well as with the abilities of inhabitants to utilize endogenous resources of the region, to appropriately apply innovations and to increase the share of value added in local and regional output. Even if the identity of inhabitants does not result from a collective memory based on regional history, culture and traditions, customer-supplier relationships among neighbouring districts and/or rural communities (Gesellschaft) could foster the local economy and have a positive impact on the external and internal image of the region - positive regional development.

The negative alternative presumes a rapid decline in the local population, significant emigration to more developed regions, and general stagnation of economic activity resulting in a negative regional image - negative regional development.

A region can, with respect to the concept of the new regional geography, be understood as a community consisting of different social groups (characterized by specific biological, economic, social, political and cultural features or interests) and their corresponding institutional structures (Matlovič 2006). According to Maslow's theory and developmental psychology, human needs are often portrayed in the shape of pyramid, the hierarchical system adopted by Č́p, Mareš (2001). The most fundamental layers consist of, among others, social and safety needs that are closely connected to the next layer of emotional needs, particularly feelings of belonging to and acceptance in a social group the regional identity.

To summarize, this is how regional identities manifest themselves at both the individual and institutional level. Moreover, sociological literature frequently uses the term existential space in the context of territorial identity (Pargač, Tomandl 1997; Spalová 2003; Zich 2003) ${ }^{3}$.

Spalová (2003) differentiates three spaces: physical (the praxis, identification and symbolic space); communicational (e.g. the socio-spatial network of partners in communication); and mental space (the inner space of an individual, disregarding residence, location or physical space). Zich (2003) defines another hierarchical structure of the existential space concept by emphasizing the complexity and interconnection of both aspects of regional identity

3 For more details on Czech and Slovak regional specifics: Siwek, Bogdová (2007); Veselovský (2006); Bilic, Krogmann (2010) and especially for territorial identity analyses: Nikischer (2013). 
(considering various spatial and social units or structures) in the theoretical and ideological view.

The concept of identity also appears in cultural geography, ethnography, folklore and other fields. One's individual (personal) identity is a culturallydetermined construct, closely associated with a certain culture; nevertheless, literature offers the term cultural identity as interconnected not only with the culture itself but also with a specific region. The boundaries of such cultural regions are not precisely defined and usually do not correspond to administrative divisions; however, they can be deeply rooted in the minds of the local population. Chromý (2003a) points out that regional identity formation is not totally dependent on the institutionalization of a region. Regions that have lost their former positions during the process of dynamic transformation of regional structures are still embedded in the memories of some native residents (Chromý 2003b).

Oring (1994) in his folklore-oriented article "Arts, Artifacts and Artifices of Identity" argues that one's personal identity (including its various aspects, such as territorial) is entrenched in an individual's inner space and might be demonstrated and perceived through his or her behaviour, (non)verbal speech, material artefacts, etc. Thus, the concept of identity is really necessary to create the precise definition of folklore. Similarly, Zástěra (2001) uses music as a manifestation of cultural identity, especially folk songs that illustrate the daily routine and clearly depict the lifestyle of previous generations. In addition, the major role of regional literature, songs, dances or even movies in the formation of collective identity is emphasized in the study by Chromý (2003b).

On one hand Vencálek (1998) highlights the importance of individual memory for the process of forming personal identity while on the other hand he accepts collective (cultural) memory as significant for cultural identity or for identity in general. The loss of continuity in collective memory leads to deformation of identity and to a gradual decline into oblivion that can be arrested by tangible and intangible artefacts that immortalize traditions and the specific characteristics of a particular region.

From the point of view of ecology or environmental geography, an individual's identification with a certain place and cultural landscape is considered as the principal objective. Landscape identity is determined by its distinctive (physical) features and cultural-historical development so that the character of landscape is affected by continuous past development and the visual landscape not only has aesthetic significance but also portrays hidden spiritual, historical and cultural meanings (Vorel 2006). The cultural landscape and its memory offer a rich source of data collection for behavioural analysis of the socio-ecology of society (Mikšíček 2003).

\section{Methodology}

Various theoretical studies focused on national and cultural identity, national pride and the identification of inhabitants with local administrative units and social groups served as sources of inspiration for this survey. For Heřmanová and Chromý (2009), Shamai and Kellerman (1985) or Hall (1980), folk customs 
and traditional rural (folklore) festivals can be considered as the primary indicator of the identification of inhabitants with their cultural heritage and the cultural-historical potential of a region. The choice of research questions used in this survey respects the works of Vondrušková (2000), Heřmanová (2008) and Zemánek (2003) and the theoretical-methodological concept of regional institutionalization stated by Silverman (2000) and Lagendijk, Cornford (2000). Through its representative research, the Institute of Sociology of the Slovak Academy of Sciences significantly contributed to the investigation of national identity in Central Europe in 1996. Piscová (1996) points out the complexity and ambiguity of national identity, because today many aspects of this issue have faced radical changes; in particular, the role (meaning) of ethnicity, culture, globalization and nationalism.

The basis of this research was the compilation of a set of questions dealing with the identification of respondents with a region, place and social groups, as well as the self-reflection of inhabitants in regard to the cultural-historical potential of their specific region. Data was collected during a survey with the working title "The Identity of Slovak Regions" from May 15 to September 15, 2011. We adjusted the sampling in accordance with Slovakia's Act No. 369/1990 Coll. on Municipal Establishment. Our respondents consisted primarily of elected municipal officials such as mayors, deputy mayors, members of municipal councils and other employees of municipalities, representing the executive leadership of local and regional self-governing units. It would not have been possible to conduct personal interviews using the PAPI (paper and pencil) method with such an extensive sample of respondents, so a less complicated form of an online questionnaire was used.

The web portal iAnkety.sk was used for preparation and publication of our web-based survey. The paid version of the web portal was used so that respondents would not be disturbed by any advertisements. Moreover, the registration and control of IP addresses prevented the same person from responding more than once. The other advantages of this software design were automatic backups and ongoing analyses of results in specific time intervals. The interim and final results were subsequently evaluated using Microsoft Excel software. The software design provided respondents with access control in real time and data verification permitted once again contacting those who had not completed the questionnaire. Additionally, advanced software features (e.g. branching) prevented the registration of multiple or incomplete answers. The web page iAnkety.sk provided:

- a summary of results, graphs and percentages

- an overview of respondents (each participant's personal data)

- analyses of answers (in Microsoft Excel)

- the possibility to share results (by a specific web link or banner).

The advantages of this method, in comparison with personal or telephone interviews, were cost savings, inexpensive and fast processing of the data in their electronic form (for more details see Zhang 2001; Cobanoglu, Warde, Moreo 2001). Respondents were mostly contacted via email; then social networks and Internet portals focusing directly on public opinion research were used. However, certain disadvantages and deficiencies in this interview process had to be considered: 
- the question of survey reliability - the selected sample of respondents (all were Internet users) may or may not express the same preferences or behavioural patterns as the whole population

- clear and comprehensible instructions - allowing self-completion of the questionnaire and consideration of different levels of IT literacy in various age categories, etc.

- the e-mail providing the survey link might sometimes be classified as spam (an unsolicited bulk e-mail)

- the settings and technological options of various web browsers (unsupported software, etc.)

Considering the extent and character of the target group, a set of closed-end questions was preferred and the respondent then chose the most appropriate and truthful answer from the offered choices. We received 4,326 electronic interviews out of the total number of 10,034 emails sent and then focused on reduction of the sample, with the final result being 2,114 respondents (Table 1). Thus, our survey should be considered as an extensive web-based survey undertaken with respondents from Slovak self-governing regions with the results further used for generalization and interpretation of the responses.

Elected municipal officials such as mayors, deputy mayors, members of municipal councils, and other employees of municipalities are considered to be representatives of the local elites. The sample of respondents was then subdivided into four categories: urban dwellers; rural dwellers, native residents and immigrants. Adverse consequences of this subdivision were taken into consideration; for example, the category of urban dwellers logically includes both native residents and immigrants living in a town or city. Nevertheless, with respect to the main aim, conditions and type of research, these four categories of respondents were considered appropriate:

1. Representatives living in towns/cities (urban dwellers) - respondents who lived in municipalities with city status under Act No. 369/1990 Coll. on Municipal Establishment.

2. Representatives living in villages (rural dwellers) - respondents who lived in municipalities without city status with dominant functions such as agriculture, recreation, and residences with typical low-country houses.

3. Representatives of native residents - respondents who were living in their birthplace during the survey period.

4. Representatives of immigrant residents - respondents who no longer were living in their birthplace during the survey period.

The questions were transformed into a uniform scale using a standardized variable. Five basic clusters, explicitly shown in the Figures $1-9$, were defined by applying hierarchical cluster analysis (clustering). This method is based on specific groups of individual objects more similar to each other than to those of other groups (clusters). Furthermore, the method of so-called single linkage or "nearest neighbour" was used in which the distance between two clusters meant the distance between the two nearest neighbours. The objects were linked up to the set number of five clusters. 


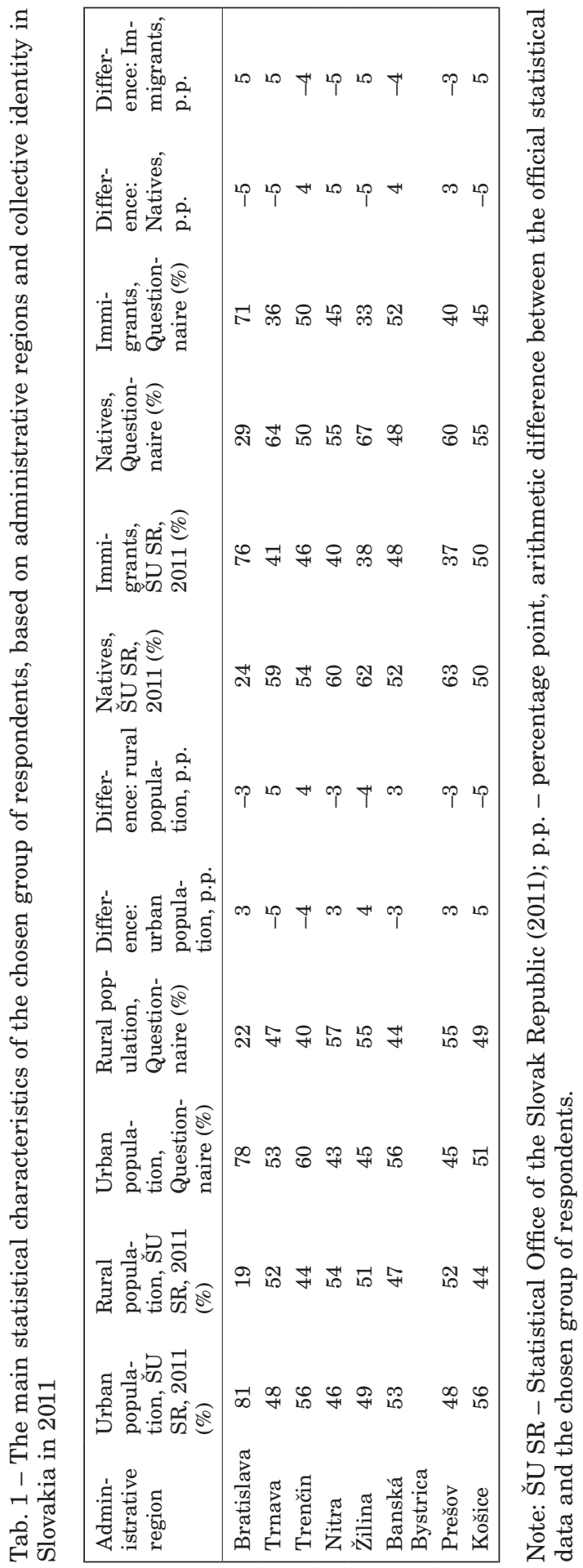


Results of previous research (e.g. Chromý 2003a) correspond with our research questions (in accordance with concepts of the new regional geography) oriented on social relations, cultural structures and/or organizations of native residents, immigrants, urban and rural dwellers in Slovakia's self-governing regions. Consequently, the basic set of entities was divided into four categories according to the identification of respondents with a particular region or place as follows: the collective identity of native residents and immigrants (those living somewhere other than their birthplace), and the urban and rural populations of the self-governing regions in Slovakia.

Three groups of responses, reflecting the core triangle of cultural geography objectives: space - society - culture, were identified by subsequent in-depth analysis and generalization. The indicator of respondents' participation in and relationship to their regional cultural heritage and socio-cultural potential were verified using the following questions (in their questionnaire order):

1. In your place of residence (in the city or municipality), you can be seriously proud of... (multiple-choice question, please, mark the answers): (1) the current economic situation, (2) local sport activities, (3) the mentality and hospitality of locals/residents, (4) local customs and traditions, (5) local architecture, (6) personalities/celebrities, (7) local (regional) history, (8) natural beauty, (9) healthy environment.

2. Can you identify a certain place (a city or municipality) in Slovakia to which you have a really close relationship and which you understand as your birthplace? (A) yes, it is my place of residence, (B) yes, but it is not my place of residence, $(\mathrm{C})$ no.

3. Please mark the activities or institutions that are located in or (annually) take place in your place of residence (in the city or municipality): (1) local folk groups and various associations, (2) local (regional) mass media (newspapers, radio, TV), (3) institutions with regional symbols in their name/title, (4) regional holidays (not celebrated elsewhere).

These above-noted research questions (from the survey questionnaire "The Identity of Slovak Regions") were selected as the most relevant for our research. The new regional geography has disproved the traditional concept of regions as closed (bounded) systems taking into consideration not only geographical community but also other social sciences (sociology, political science, ethnology). In this framework, a regional system is constructed by close social interrelations and its cultural-historical meaning (the social construct).

Halás (2008) pointed out that the self-governing regions of Košice and Prešov belong among the least developed territories in the Slovak Republic and among ten least developed regions of the European Union. This is a consequence of the difficult transformation process in the region, insufficiently developed transport, technological, and civic infrastructure, but also influence of the peripheral position of the region within Slovakia (not merely from the geographical distance viewpoint but also from partially organizational and institutional separation). 


\title{
4. The Perception of Socio-Cultural Identity by Local and Regional Officials
}

\author{
4.1. Local Pride as the Demonstration \\ of (Local) Patriotis m
}

First, the respondents chose options that most accurately illustrated their perception of local pride. "Natural beauty" (Fig. 1) and "local (regional) history" (Fig. 2) dominated in all of Slovakia's self-governing regions. It was observable especially in Cluster III (the Žilina, Banská Bystrica and Trenčín self-governing regions). Despite the differing collective identities of regional council members, these three self-governing regions offer high natural potential for tourism. Moreover, these regions encompass 75\% of protected areas in Slovakia with either the second grade (protected landscape areas $=\mathrm{CHKO}$ ) or the third grade (national parks $=$ NP), as well as territories of European importance (Severopovažský, Liptovský, Horehronský and Tatranský) and areas of national tourist importance (Strednopovažský, Turčiansky and Oravský).

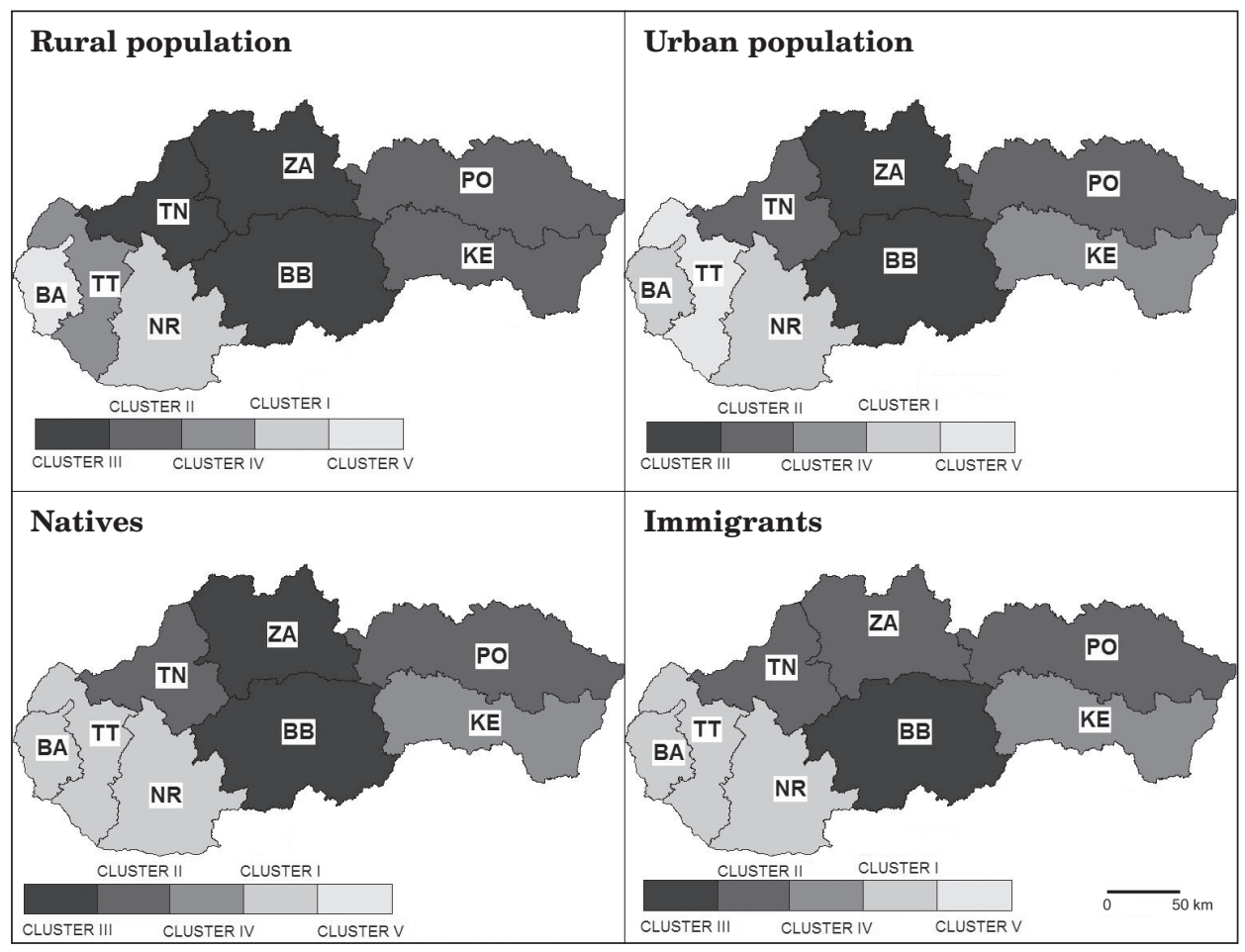

Fig. 1 - Clusters according to local pride in natural beauty. The most frequent answer to the question about whether respondents $(n=2,114)$ are proud of its "natural beauty". The share of positive responses: Cluster III - total agreement, Cluster II - agreement, Cluster IV - partial agreement, Cluster I - disagreement, Cluster V - total disagreement. Self-governing regions: BA - Bratislava, TT - Trnava, NR - Nitra, TN - Trenčin, ZA - Žilina, BB - Banská Bystrica, PO - Prešov, KE - Košice. Source: The database of the survey questionnaire. 


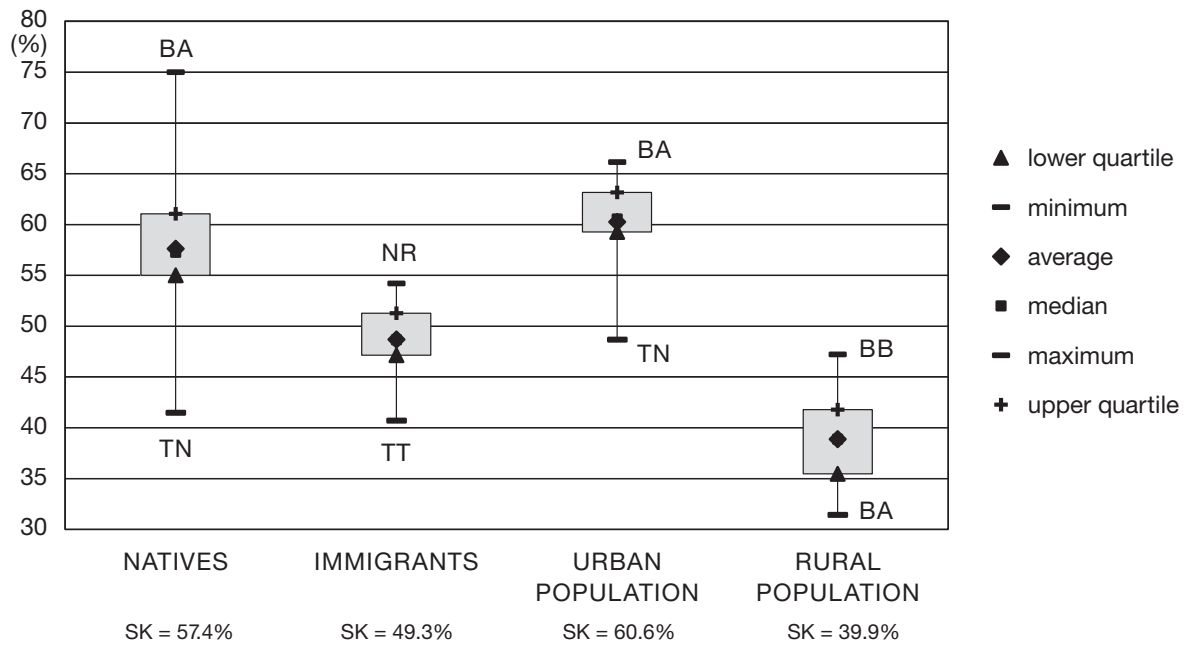

Fig. 2 - The subdivision of respondents (\%) considering pride in their local history. The second most frequent answer to the question about what respondents $(n=2,114)$ are proud of is "local (regional) history". SK - Slovakia (average values). Self-governing regions: BA - Bratislava, TT - Trnava, NR - Nitra, TN - Trenčin, ZA - Žilina, BB - Banská Bystrica, PO - Prešov, $\mathrm{KE}$ - Košice. Source: The database of the survey questionnaire.

Second, the collective identity preferred "local (regional) history" as an adequate reason to be proud of their city or municipality. Collective memory retains essential social phenomena, experiences and events and due to this fact enables some regional historical attributes to be preserved chronologically en bloc, e.g. value orientation, symbols, customs or traditions (Fig. 2). The national average points to a different perception of history taking into consideration the urban and rural population, with the difference between the sample of urban and rural respondents being $20.7 \%$.

Traditional folk culture represents the basis of cultural identity, the "keystone" of historical background, consciousness, education and patriotism. Obviously, the third most chosen option was "the relationship to local customs and traditions" as the reason to be proud of a municipality (or a city); it was chosen by more than $43.2 \%$ of the rural population (Fig. 3 ).

Regional culture is, within the cultural identity framework, still alive, creative and looking for self-realization. The better, deeper and broader that consciousness of cultural belonging to a community (linguistically, literally, traditionally or culturally) becomes and the more that individual members of a community are emotionally and psychologically influenced by family education and local or regional traditions, the more positive and successful are these efforts. Reflection of regional culture is becoming more and more important as a factor of regional identity. It structurally incorporates active subjects, objects, creators, organizers and recipients of those activities.

From the point of view of spatial differentiation, it is observable that the native residents and the rural population judged "pride in natural beauty, history, customs, traditions" as a very significant condition for construction of 


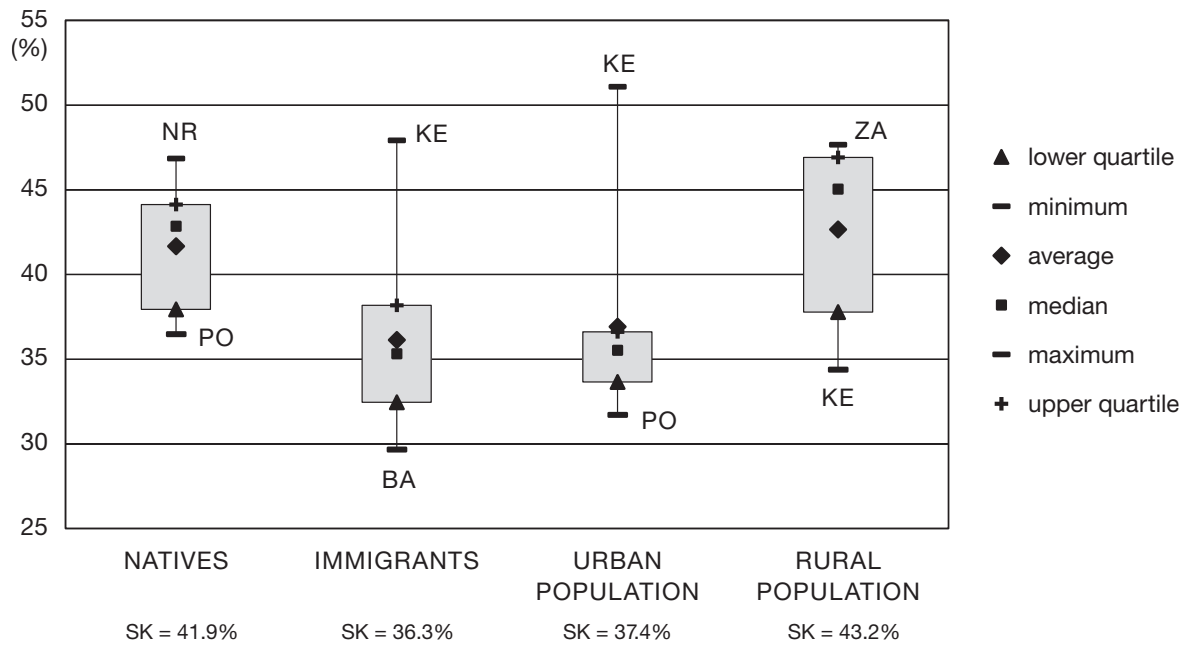

Fig. 3 - The subdivision of respondents (\%) considering pride in their local traditions. The third most frequent answer to the question about what respondents $(n=2,114)$ are proud of is "local customs and traditions". SK - Slovakia (average values). Self-governing regions: BA - Bratislava, TT - Trnava, NR - Nitra, TN - Trenčin, ZA - Žilina, BB - Banská Bystrica, PO - Prešov, KE - Košice. Source: The database of the survey questionnaire.

collective identity and local patriotism. On the contrary, the respondents in general evaluated "the current economic situation" as a less popular reason for pride (Fig. 4).

Only $4.1 \%$ of the respondents rated the local economic situation positively. The highest score was achieved in Cluster I (Bratislava - native residents as well as immigrants) and Cluster V (Bratislava - urban population). In contrast, a negative connotation was expressed by the native residents and rural population of Prešov self-governing region, immigrants of Košice region and the urban population of Banská Bystrica region, in comparing their collective identity.

Several authors, for instance Korec (2003) and Hampl (2001), draw attention to the so-called phenomenon of the East-West Gradient that considerably determines macro-localization of the Visegrad Group (V4) countries. The regions located close to the borders with Austria (e.g. Bratislava self-governing region) have better conditions for socioeconomic development. Particularly during the transition period, these regions adapted more smoothly to new trends and innovations in the industrial and economic structure, encouraging foreign direct investments flows.

The perception of threatening (risk) factors is closely related to the question of regional and local sustainable development, especially the financial policies of cities, municipalities and regions. A local identity based on and affected by regional history, customs and traditions is essential for a community but today the absence of an economic platform can lead to its extinction.

From the macro-regional point of view, recent research of regional disparities (Halás 2008) has confirmed an evident north-western - south-eastern polarization of Slovakia. The most negative results are observable for the 


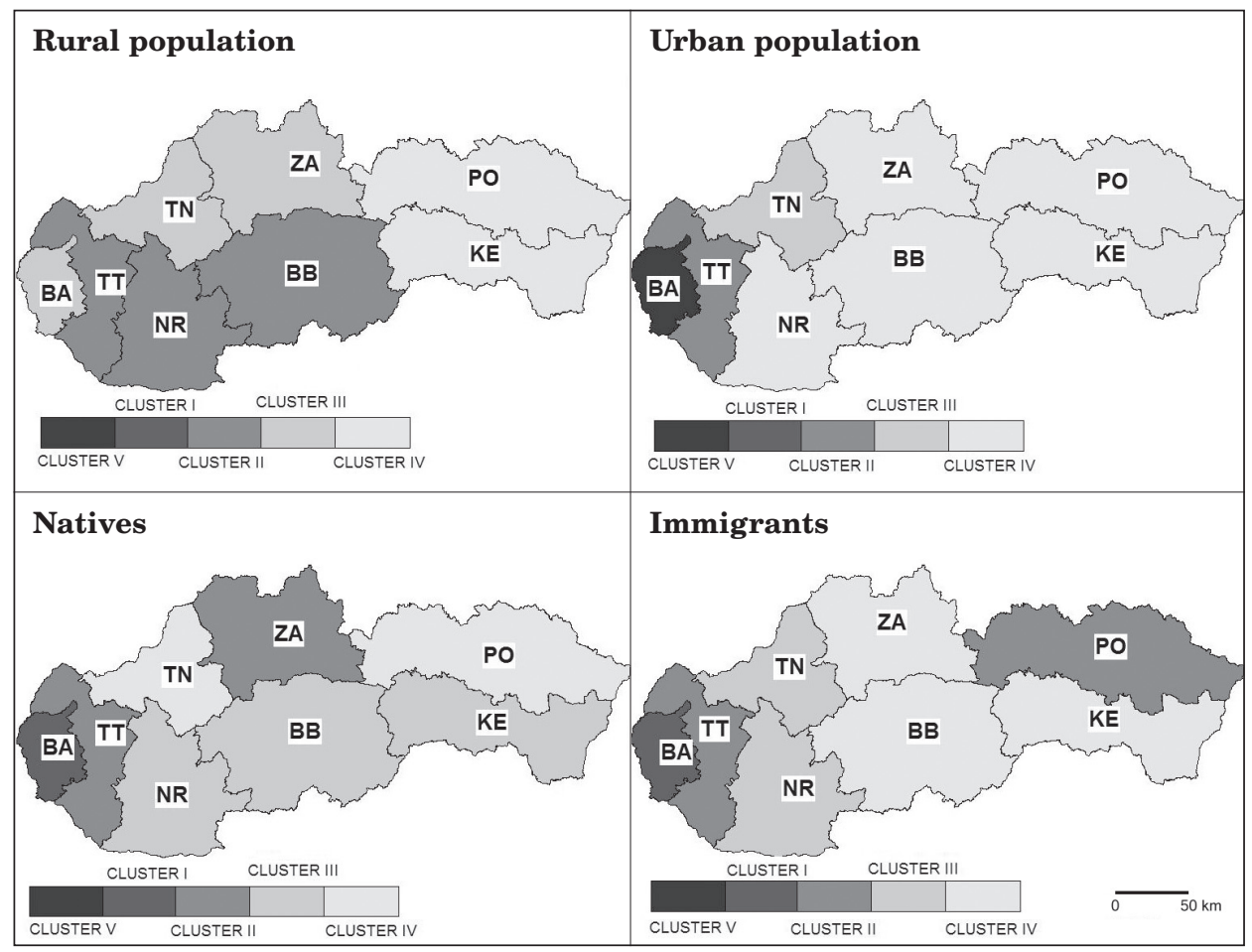

Fig. 4 - Clusters according to local pride about the current economic situation. The less frequent answer to the question what respondents $(n=2,114)$ are proud of is "the current economic situation". The share of positive responses: Cluster V - total agreement, Cluster I - agreement, Cluster II - partial agreement, Cluster III - disagreement, Cluster IV - total disagreement. Self-governing regions: BA - Bratislava, TT - Trnava, NR - Nitra, TN Trenčin, ZA - Žilina, BB - Banská Bystrica, PO - Prešov, KE - Košice. Source: The database of survey questionnaire.

south-central districts of Revúca and Rimavská Sobota (mostly its southern part) and Rožňava (the western part) and slightly less for the north-eastern districts of Medzilaborce, Snina (the western part), Stropkov and Svidník (the northern parts). One of the major causes of the poor social and economic conditions in larger regions is considerably underdeveloped transport infrastructure, the rebuilding of which could (along with other inflows and investments) be the main impulse of development. However, the quality of life is not measurable only by statistical or rated indicators and peripherality has (and always will have) only a relative meaning.

\subsection{The Relationship of Inhabitants to Locality}

The relationship of inhabitants to a city or municipality was evaluated as one of the most compelling manifestations of solidarity (fellowship) with one's territory, and thus, as a potential source of local and/or regional development. 


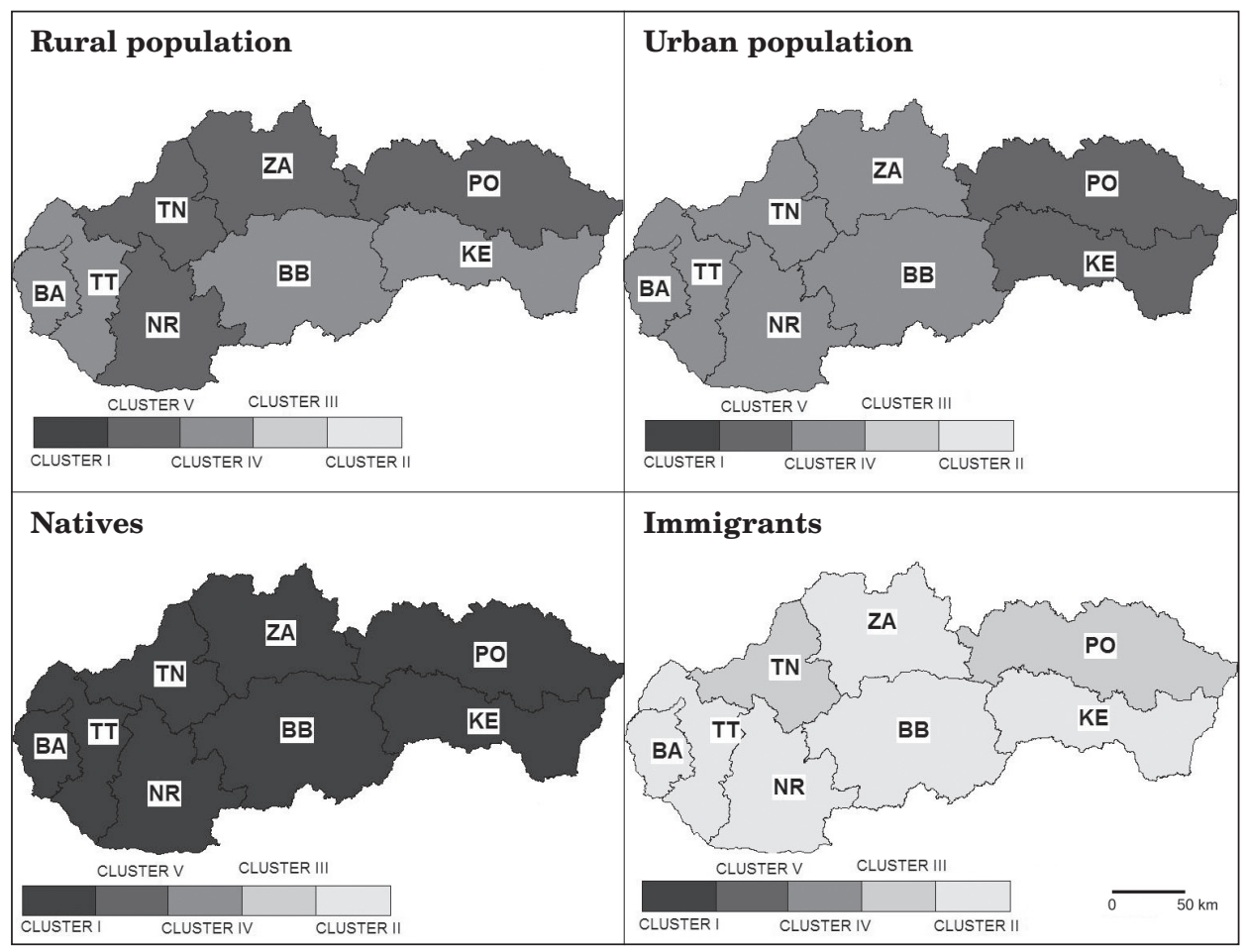

Fig. 5 - Clusters according to respondents' identification of their birthplace and current residence. The most frequent answer to the question about the city or municipality identified by respondents $(n=2,114)$ as their birthplace was that "it is identical with his/her place of residence". The share of positive responses: Cluster I - total agreement, Cluster V - agreement, Cluster IV - partial agreement, Cluster III - disagreement, Cluster II - total disagreement. Self-governing regions: BA - Bratislava, TT - Trnava, NR - Nitra, TN - Trenčin, ZA - Žilina, BB - Banská Bystrica, PO - Prešov, KE - Košice. Source: The database of the survey questionnaire.

The following question examined the existence of a city or a municipality that is recognized and honoured as the birthplace by respondents: "Can you identify a certain place (a city or municipality) in Slovakia to which you have a really close relationship and which you perceive as your birthplace?" We decided to focus specifically on the positive response, identifying the birthplace with the current place of residence.

The proximity-distance perception of a previous and current (new) place of residence is undoubtedly important for inhabitants (the native residents - the immigrants). Zich (2003) defined two basic aspects of regional identity: the relationship to (physical) space and the degree of integration or identification with social space. This author does not consider space as simply "physical"; rather he highlights its "social content". Dealing with the concept of regional identity, the interaction between a municipality, local culture and local community occurs only for native residents. Immigrants are not obviously influenced by relationships to their city or self-governing region, represented by local 
community (fellowship) or informal organizations. Therefore, they either prefer the state in general or a foreign country as their connotation of social space or do not confirm a close relationship to their birthplace, respectively, the place of residence (Fig. 5).

A fundamental assumption of one's acceptance of birthplace is not only the quality of technical, social and economic infrastructure, but also family relations. Family provides the crucial criterion for identification of local identity and, as a direct consequence, the perception of birthplace. It is said that "my home is where my family lives"; therefore, the place itself (e.g. a healthy environment) cannot be understood as the sole "touchstone" for birthplace or home.

The highest number of respondents associating their current place of residence with their birthplace (their hometown) belonged to the collective identity of native residents. On one hand, the majority of the native residents in all self-governing regions chose this option (Cluster I, Fig. 5) but on the other hand, the lowest degree of such an association was indicated by the collective identity of immigrants (Clusters II and III, Fig. 5).

In the context of European (neo)regionalism emphasizing the "bottom-up", use of regional development potential - the interest in and specific relationship of inhabitants to a particular region (Heřmanová, Chromý 2009) - a more optimistic view on these results can be taken.

The respondents identifying their current place of residence with their birthplace exhibited strong social cohesion and a preference for traditionalism and social stability. Nevertheless, the other groups of respondents, not reflecting any emotional, social or cultural relationship to place, can be characterized by a greater degree of independence, individualism and the post-modern perception of society. Instead of "belonging" to the community they preferred more formal social ties and relations.

\subsection{The Institutionalization of Place (the Region) According to Selected Types of Social Activities}

The subsequent set of questions examined the perception of local social life based on collective identity. The respondents were asked whether they had appropriately-situated institutions or annual activities taking place in their place of residence, for example local folk groups, associations, local (regional) mass media (newspapers, radio, TV), institutions with regional symbols in their name or title, regional holidays, etc. (additional answers were possible).

Most of the respondents (24.4\%) favoured "local folk groups and various associations", which represent the specific connections of traditional culture which to some extent can contribute to the revitalization or innovation of the local (regional) folk tradition. Kowalski (1999) argued that folklore itself means conscious support for the preservation of traditional culture; however, not in the form of actual functioning of folk tradition but through the production of artefacts for museums, private collectors or for sale. Folk groups, strongly influencing construction of the cultural subsystem of a region and development 


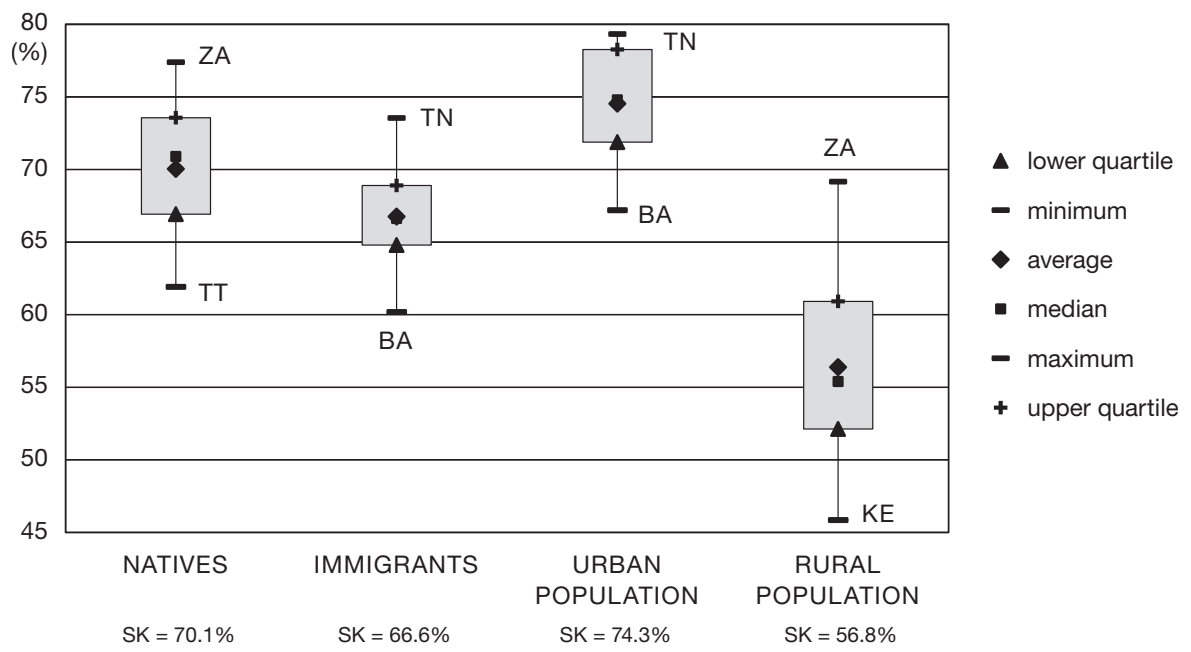

Fig. 6 - The subdivision of respondents (\%), considering their perception of folk groups. The most frequent response to the question to what respondents $(n=2,114)$ identify themselves with is "local folk groups and various associations". SK - Slovakia (average values). Selfgoverning regions: BA - Bratislava, TT - Trnava, NR - Nitra, TN - Trenčin, ZA - Žilina, BB Banská Bystrica, PO - Prešov, KE - Košice. Source: The database of the survey questionnaire.

of regional consciousness and identity, are closely connected with Slovak cities and towns; thus, they were primarily recognized by urban dwellers and native residents. Compared to only slightly more than a half of the rural dwellers (56.8\%), almost three quarters of "townspeople" noted their personal relationship to folklore (Fig. 6).

Local (regional) mass media (e.g. newspapers, TV) were in the second position according to the respondents' opinions (21.7\%). Regional symbols and visual images present an useful tool for interpretation of place within external space. The promotion of a territory itself influences the consciousness of inhabitants as well as visitors to the region. The relationship of inhabitants to a certain place is formed by both positive and negative factors. In general, local (regional) mass media belong among the main protagonists participating in progressivism or, respectively, decomposition of regional identity.

Regional media essentially contribute to the spread of local self-consciousness among inhabitants with the help of regional features (advertisements, articles), consolidate cultural identity, and incorporate citizens into public affairs and governance; finally, media can initiate regional economic progress. In assessing the print media, the most active are regional advertising newspapers and those informing about regional job opportunities, cultural events, major regional personalities and current offers on the regional property market. Nevertheless, local (regional) media have (unfortunately) only limited accessibility and impact regarding transmission of their signal and/ or transportation costs. The existence and localization of media principally depends on population density and regional economic potential. As verified by the results of this analysis, it can be stated that the majority of mass media 


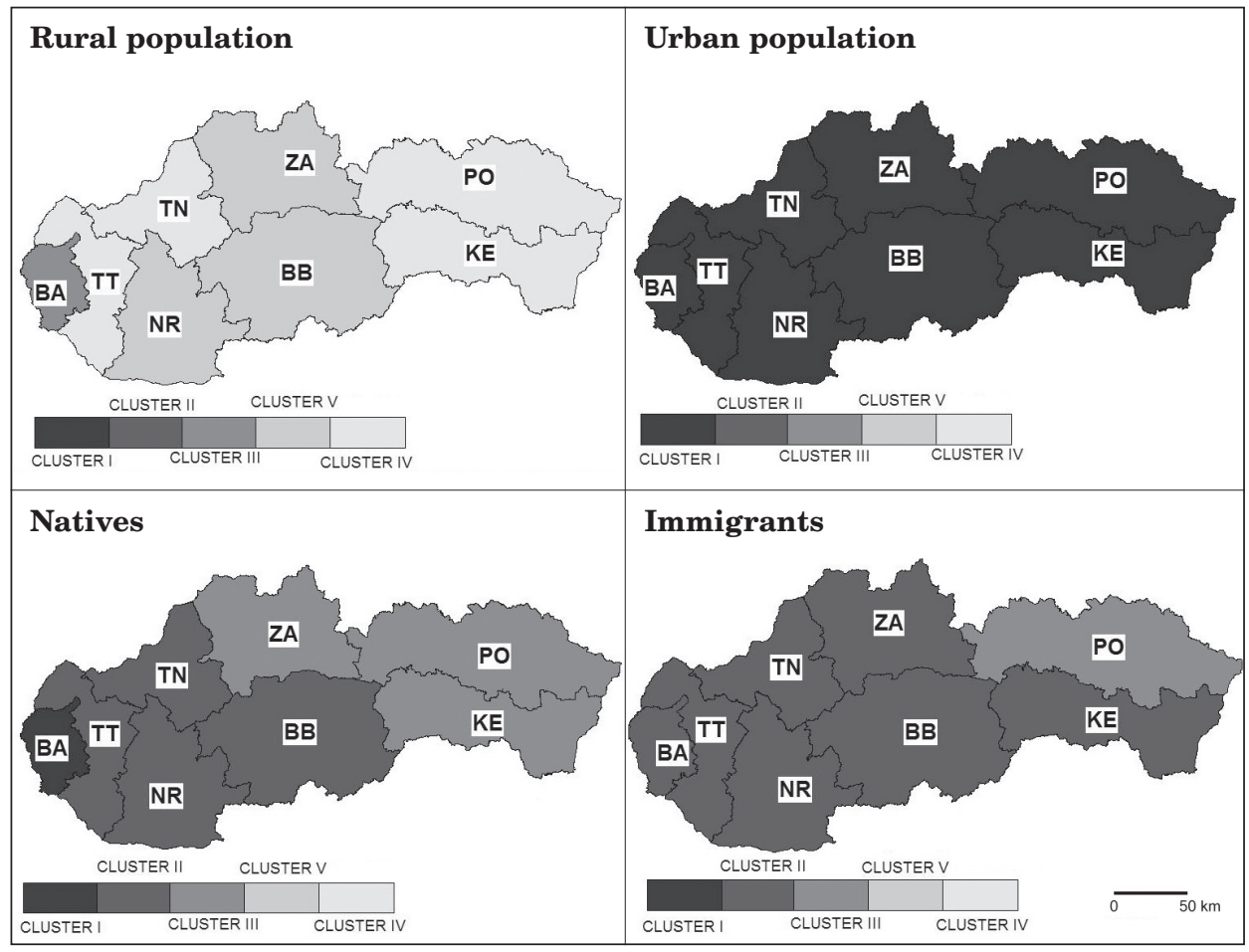

Fig. 7 - Clusters according to access to local (regional) media The most frequent answer of respondents $(n=2,114)$ to the question evaluating a region according to "the existence of local (regional) mass media”. The share of positive responses: Cluster I - total agreement, Cluster II - agreement, Cluster III - partial agreement, Cluster V - disagreement, Cluster IV - total disagreement. Self-governing regions: BA - Bratislava, TT - Trnava, NR - Nitra, TN - Trenčin, ZA - Žilina, BB - Banská Bystrica, PO - Prešov, KE - Košice. Source: The database of the survey questionnaire.

is concentrated in cities due to the required infrastructure. All self-governing regions of Clusters IV and V lack sufficient access to local (regional) media (Fig. 7).

Next, symbolism plays a meaningful role in the process of regional institutionalization. Otherwise, a region loses its historical continuity not only from the spatial point of view but also in its relationship with inhabitants. The importance of regional names provides an essential basis for the internal and external (self-) image; therefore, they help to protect well-preserved images of the region in collective memory that today remains a valuable source of local information. Each symbol provides an individual character to a region and guarantees its spatial identification.

As mentioned earlier, organizations and institutions remain in the central position, taking into account the formation of a region and the continuation of regional identity and symbolism. In this area, formal relations are supported by social clubs, schools, non-government organizations, firms, and institutions of local and regional governments. Meanwhile, informal relations (friendships) 


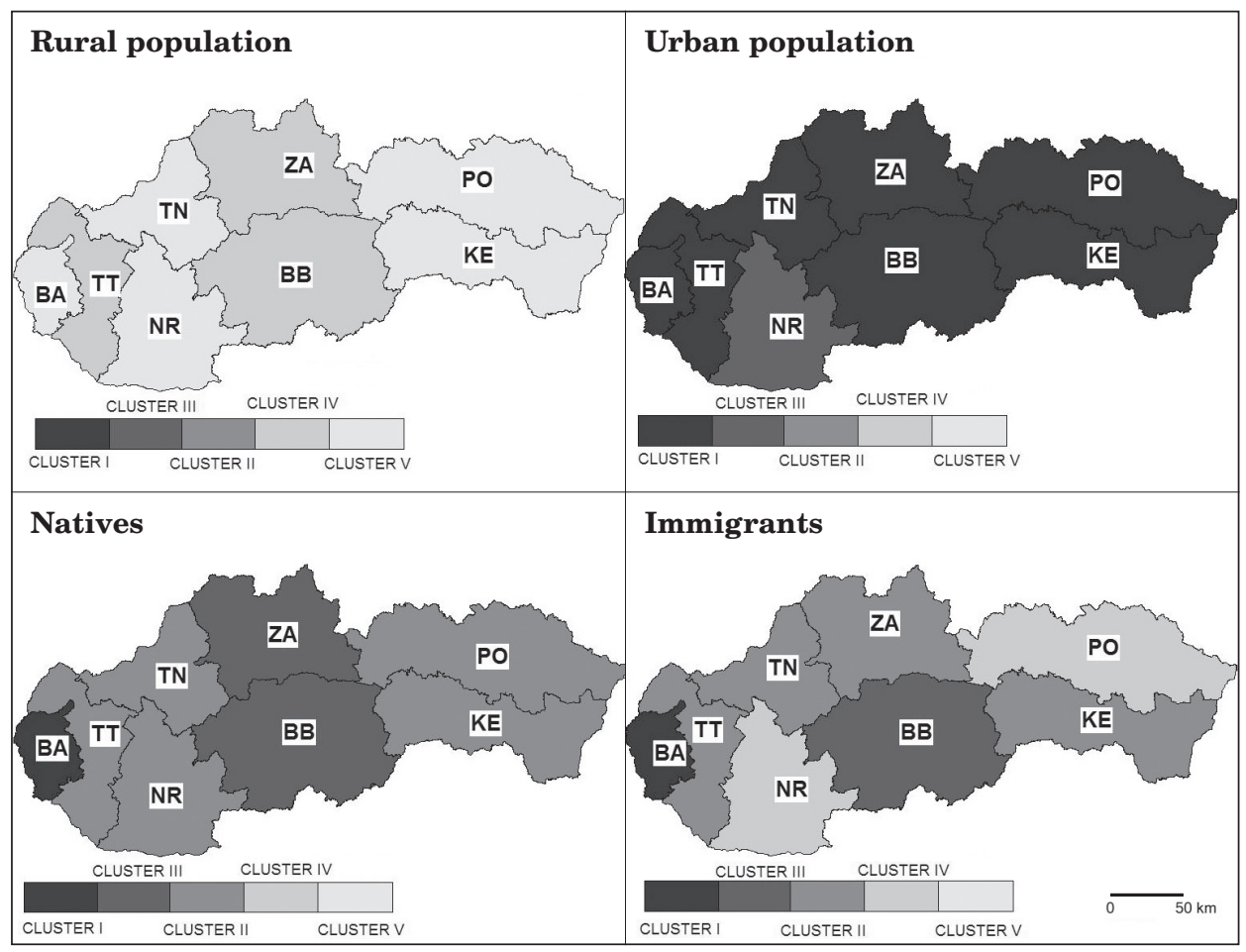

Fig. 8 - Clusters according to respondents` emphasize of the existence of symbolically-named regional institutions. The proportion of respondents $(n=2,114)$, emphasizing the existence of symbolically-named regional institutions analysed in percentage terms. The share of positive responses: Cluster I - total agreement, Cluster III - agreement, Cluster II - partial agreement, Cluster IV - disagreement, Cluster V - total disagreement. Self-governing regions: BA - Bratislava, TT - Trnava, NR - Nitra, TN - Trenčin, ZA - Žilina, BB - Banská Bystrica, PO - Prešov, KE - Košice. Source: The database of the survey questionnaire.

emerge as a direct effect of the same (and daily) kinds of behaviour and the lifestyle in a community.

According to the Law No. 302/2001 § 7 Paragraph 2, a self-governing region submits a proposal to the Ministry of Interior of the Slovak Republic for its symbols to be registered into the Heraldic Registry of the country. Moreover, according to $\S 1$ Paragraph 6 of the law, each self-governing region has its own symbols (e.g. a coat of arms, flag and seal/emblem) used in execution of local and/or regional government functions.

The highest values recorded for identification of institutions with regional symbols in their names came from native residents and urban dwellers, particularly in Clusters I and II (Fig. 8). These respondents more frequently come into contact with regional institutions and services within the scope and jurisdiction of a self-governing region (these offices are usually concentrated in a city centre).

The construction of modern society's spatial identity is influenced by the phenomenon of historical memory, representing the impression of urban 


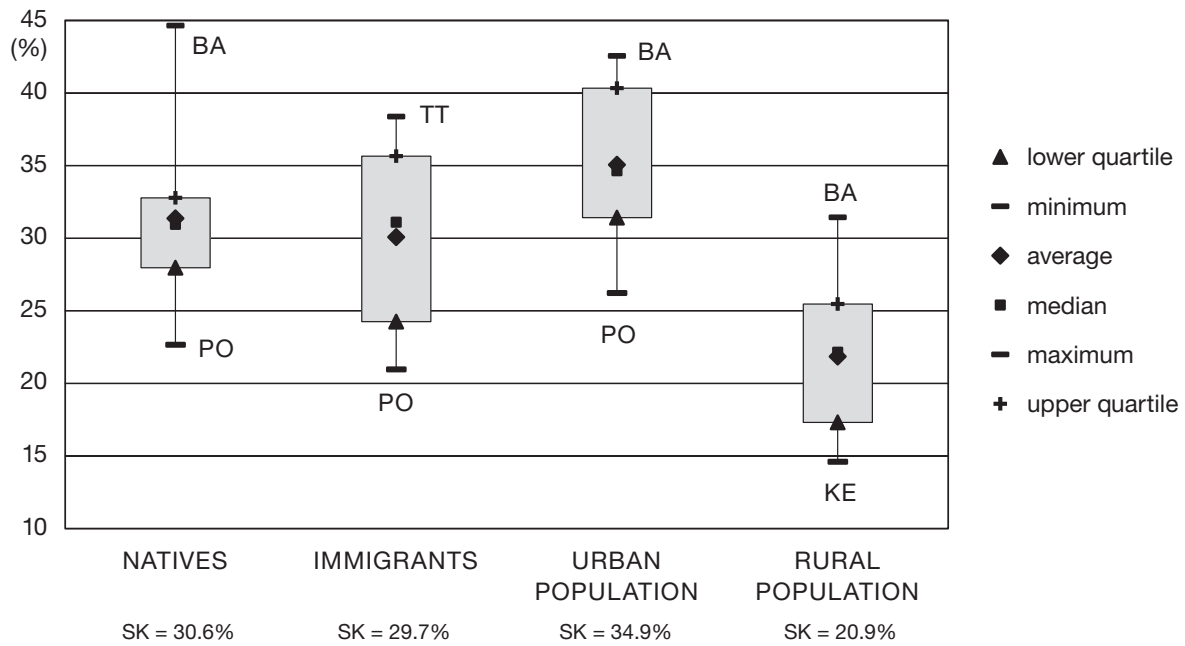

Fig. 9 - The subdivision of respondents (\%), considering awareness of unique regional holidays. The proportion of respondents $(n=2,114)$ aware of specific unique regional holidays (usually held annually) analysed in percentage terms. Self-governing regions: BA - Bratislava, TT - Trnava, NR - Nitra, TN - Trenčin, ZA - Žilina, BB - Banská Bystrica, PO Prešov, KE - Košice. Source: The database of the survey questionnaire.

anthropogenic activity. Individual, social and collective memory plays a vital role in identification of social and cultural processes in a region. From this point of view, religious and collective family memory can also be included. Then, the elementary premise of the entire process is the ability to retain special social phenomena, events and experiences: for example, celebrations of a city's founding or other local (regional) religious or secular ceremonies and festivals. The memories themselves are rooted in the (in)tangible cultural heritage of a particular region; for instance, certain still-practiced traditions are typical: burning or drowning an effigy of Marzanna ${ }^{4}$, the erection of maypoles, the Shrove Tuesday Carnivals (Fašiangy) and Easter and Christmas customs.

The last examined option considered regional festivities as a reflection of intangible local or regional culture that is not celebrated elsewhere (in other Slovak cities and municipalities). A contrast between urban and rural dwellers is markedly observable. Optimal conditions for these kinds of festivities were in the Bratislava and Trnava elf-governing regions (Fig. 9) which are ethnically heterogeneous areas historically affected by Slavic (Czech, Slovak), Germanic (Austrian) and Finno-Ugric (Hungarian) culture where there is a higher probability (and presumption) of ethnic differences.

4 The drowning of Morena is a pagan custom in Czechia and Slovakia that takes place two weeks before Easter. This holiday is the traditional Czech and Slovak way to say farewell to winter. 


\section{Conclusion}

The empirical analyses confirm the general prediction that the strongest regional identities are most distinctive for native residents and rural dwellers. The phenomenon of cultural-historical memory contributes to the building of territorial identity, while its symbolic and emotional dimension represents the traditions received by collective identity through cultural symbols and anthropogenic artefacts. The effects of social and cultural-historical memory are more evident at the local and regional level. In this context, the so-called "sacralisation" of a historic city involving an annual commemoration of major holidays and local (regional) historical events can be mentioned. A memorial day can be understood as a metaphorical reminiscence of a common important success, the rebirth of an idiosyncratic cultural identity. The respondents defined a holiday or an anniversary of the local community as an essential structural instrument in the process of activating local identity. The relevance of this concept in socio-cultural space remains valid not only for traditional holidays (e.g. "City Days") but as well for eccentric celebrations that retain conspicuous and significant features of the specific territory.

Collective memory, as well as its social relations, has been created by the cultural-historical and mental traditions established in a particular region over time. The natural development of a cultural-historical identity in essence depends on the process of its gradual historical acceptance by inhabitants. A correlation between the quality of cultural-historical heritage and the economic situation of a municipality cannot be unequivocally confirmed; nevertheless, a proactive approach by local inhabitants often ameliorates problems arising from negative financial and administrative issues and geographical location. Historical development and continuity could give an impulse to socio-economic progress, specifically reflecting the character of the socio-demographic psyche of inhabitants.

The cultural heritage and cultural-historical potential of Slovak regions is not fully exploited with respect to the opportunities open for domestic and foreign (cultural) tourism. Actually, a general consensus among experts about the conceptions of appropriate presentation and adequate implementation of the significant cultural potential of regions does not currently exist.

Considering the various quantitative results (Figures 1-9) that illustrate the opinions and attitudes of respondents toward (in)tangible elements of cultural heritage, it seems to be truly complicated to find, and even more difficult to define, a causal spatial differentiation and perception of socio-cultural identity. Finally, respondents in our survey declared their key interest in urban and rural (country) folk groups, associations, and local and regional mass media (newspapers, TV). Hence, we characterize the relationship as: culture - local identity - society. 


\section{References:}

AGNEW, J.A. (1989): Nationalism: Autonomous Force or Practical Politics? Place and Nationalism in Scotland. In: Williams, C.H., Kofman, E. (eds.): Community Conflict, Partition and Nationalism, Routledge, London, pp. 94-167.

APPADURAI, A. (1996): Modernity at Large: Cultural Dimensions of Globalization. University of Minnesota Press, Minneapolis, $229 \mathrm{pp}$.

BILIC, M., KROGMANN, A. (2010): Vplyv vybraných ekonomických ukazovatelov na atraktivitu regiónov SR z pohladu zahraničnej migrácie v roku 2008. Geographia Cassoviensis, 4, No. 1/2010, pp. 16-23.

COBANOGLU, C., WARDE, B., MOREO, P. (2001): A Comparison of Mail, Fax, and Webbased Survey Methods. International Journal of Market Research, 43, No. 4, pp. 441-452.

COHEN, S.B., KLIOT N. (1992): Place-Names in Israel and Ideological Struggle over the Administered Territories. Annals of the Association of American Geographers, 82, pp. 653-680.

ČÁP, J., MAREŠ, J. (2001): Psychologie pro učitele. Portál, Praha, 655 pp.

EISENSTADT, S.N., GIESEN, B. (1995): Construction of Collective Identity. Archives de Sociologie, XXXVI, pp. 72-84.

ERIKSSON, M. (2008): (Re) Producting a "Peripheral" Region - Northern Sweden in the News. Geografiska Annaler B90, pp. 369-388.

HALÁS, M. (2008): Priestorová polarizácia spoločnosti s detailným pohladom na periférne regióny Slovenska. Sociologický časopis / Czech Sociological Review, 44, No. 2, pp. 349-369.

HALL, S. (1980): Cultural Studies and the Centre: Some Problematics and Problems. In: Hall, S. et al. (eds.): Culture, Media, Language. Hutchinson/Centre for Contemporary Cultural Studies, London, pp. 15-47.

HAMPL, M. (2001): Geografie transformace v České republice: celkové zhodnocení. In: Hampl a kol.: Regionální vývoj: specifika české transformace, evropská integrace a obecná teorie. Univerzita Karlova, Praha, pp. 27-41.

HEŘMANOVÁ, E. (2008): Vykořeněné a nevykořeněné obce (na příkladu vybraných obcí Tachovska a Domažlicka). In: Šimůnek, R. (ed.): Regiony - časoprostorové průsečíky? Monografie ze stejnojmenné konference konané 23. 1. 2008. Historický ústav AV ČR, Praha, pp. 192-213.

HEŘMANOVÁ, E., CHROMÝ, P. a kol. (2009): Kulturní regiony a geografia kultury. ASPI, a. s., Praha, 348 pp.

CHROMÝ, P. (2003a): Formování regionální identity: nezbytná součást geografických výzkumů. In: Jančák, V., Chromý, P., Marada, M. (eds.): Geografie na cestách poznání. Univerzita Karlova v Praze, Př́rodovědecká fakulta, pp. 163-178.

CHROMÝ, P. (2003b): Memory of Landscape and Regional Identity: Potential for Regional Development of Peripheral Regions. In. Jeleček, L., Chromý, P., Janů, H., Miškovský, J., Uhlírová, L. (eds): Dealing with Diversity: $2^{\text {nd }}$ IC of the ESEH Prague 2003, Proceedings. Charles University in Prague, Faculty of Science, Department of Social Geography and Regional Development, Prague, pp. 246-256.

KOREC, P. (2003): Population development, urbanization and regional disparities of Slovakia. Acta Uniersitatis Carolinae, 2003, No. 1, pp. 167-180.

KOWALSKI, P. (1999): O manipulovaniu kultura ludowa. In: Jakubíková, K. (ed.): Tradícia, etika a civilizačné zmeny. Bratislava, pp. 35-45.

LAGENDIJK, A., CORNFORD, J. (2000): Regional Institutions and Knowledge-tracking: New Forms of Regional Development Policy. Geoforum, 31 (2000), pp. 209-218.

MATLOVIČ, R. (2006): Geografia - hladanie tmelu. K otázke autonómie a jednoty geografie, jej externej pozície a inštitucionálneho začlenenia so zretelom na slovenskú situáciu. Acta Facultatis Studiorum Humanitatis et Naturae Universitatis Prešoviensis: Folia Geographica, 9, pp. 6-43.

MEIER-DALLACH, H.P. (1980): Räumliche Identität - Regionalistische Bewegung. In: Information zur Raumentwicklung, Heft 5/1980, pp. 301-313.

MIKŠÍČEK, P. (2003): Genius loci kulturní krajiny, Sudetské zvlášte. In: Tvář naší země krajina domova. Sborník př́íspevků ke konferenci konané ve dnech 8.-10. 3. 2003. 3, pp. 41-50. 
MINGIONE, E. (1994): Life Strategies and Social Economies in the Postfordist Age. International Journal of Urban and Regional Research, 18, No. 1, pp. 24-44.

NIKISCHER, R. (2013): Teritoriálna identita obyvatelov Česka a Slovenska. Geografie, 118, No. 3, pp. 243-264.

ORING, E. (1994): Arts, Artifacts and Artificies of Identity. The Journal of American Folklore, 107, No. 424, pp. 211-233.

PAASI, A. (1986):The Institutionalization of Regions: A Theoretical Framework for Understanding the Emergence of Regions and the Constitution of Regional Identity. Fennia, 164, No. 1, pp. 105-146.

PAASI, A. (2001): Europe as a Social Process and Discourse: Considerations of Place, Boundaries and Identity. European Urban and Regional Studies, 8, No. 1, pp. 7-28.

PAASI, A. (2003): Region and Place: Regional Identity in Question. Progress in Human Geography, 28, No. 4, pp. 475-485.

PAASI, A. (2004): Place and Region: Looking Through the Prism of Scale. Progress in Human Geography, 28, No. 4, pp. 536-546.

PARGAČ, J., TOMANDL, M. (1997): Žitý prostor a jeho subjektivizace u nositelů lokálního a regionálního vědomí, Acta Universitatis Carolinae: Philosophica et Historica 3 Studia Etnographica, 10, pp. 57-70.

PISCOVÁ, M. (1996): Postoje a očakávania obyvatelov SR k integračným procesom a európskym štruktúram. Národná Identita - premenná publikácia z výskumu. Sociologický ústav SAV, Bratislava, 93 pp.

SABEL, C.F. (1992): Studied Trust: Building New Forms of Co-operation in a Volatile Economy. In: Pyke, F., Sengenberger, W. (eds.): Industrial Districts and Local Economic Regeneration. International Institute for Labour Studies, Geneva, pp. 37-51.

SHAMAI, S., KELLERMAN, A. (1985): Conceptual and Experimental Aspects of Regional Awareness: An Israeli Case Study. Tijdschrift voor Economische en Sociale Geografie, 76, pp. 88-99.

SILVERMAN, D. (2000): Doing Qualitative Research. A Practical Handbook. London, 327 pp.

SIWEK, T., BOGDOVÁ, K. (2007): České kulturně-historické regiony ve vědomí svých obyvatel. Sociologický časopis / Czech Sociological Review, 43, No. 4, pp. 1039-1053.

SPALOVÁ, B. (2003): Když to pude, já se vocad’ nehnu (Lokální a regionální identita kulurních elit v pohraničí). In: Zich, F. (ed.): Regionální identita obyvatel v pohraničí. Sborník příspěvků z konference „Evropská, národní, či regionální identita?“ Praha, 3. 10. 2003. Sociologický ústav AV ČR, pp. 81-92.

SPILLING, O.R. (1991): Entrepreneurship in a Cultural Perspective. Entrepreneurship and Regional Development 3, pp. 33-48.

SWEENEY, G.P. (1990): Indigenous Development Strategies in Peripheral Regions: The Example of Ireland. In: Ewers, H., Allesch, J. (eds.): Innovation and Regional Development: Strategies, Instruments, and Policy Co-ordination. Walter de Gruyter, Berlin, 265 pp.

STATISTICAL OFFICE OF THE SLOVAK REPUBLIC (Štatistický úrad Slovenskej republiky) (2011): Volby do orgánov samosprávy obcí 2010, http://app.statistics.sk/kv2010/menu/ indexD.jsp?lang=sk (25.9.2011)

TANGKJAER, CH., LINDE-LAURSEN, A. (2004): Place-making in the global village Oresund. A brand new future? In: Zimmermann, F.M., Janschitz, S. (eds.): Regional Policies in Europe. Soft Features for Innovative Cross-border Cooperation, Graz, pp. 9-31.

THRIFT, N. (1998): Towards a new New Regional Geography. Berichte zur deutchsen Landeskunde 72, Heft 1, pp. 37-46.

VENCÁLEK, J. (1998): Protisměry územní identity. OLZA, spol. s r. o., Český Těšín, 207 pp.

VESELOVSKÝ, J. (2006). Vybraný sociálny indikátor TUR - chudoba a jej meranie. Geografická revue, 2, No. 2/2006, pp. 220-226.

VONDRUŠKOVÁ, A. et al. (2000): Od folklóru k folklorismu - Čechy, Slovník folklorního hnutí v Čechách. NÚLK, Strážnice, 171 pp.

VOREL, I. (2006): Krajinný ráz a jeho ochrana. 1. Část - Charakter, ráz a identita krajiny. Ochrana přírody, 61, No. 9, pp. 262-265.

ZÁKON 302/2001 (Law No. 302/2001) Z. z. o samospráve vyšších územných celkov. Zákon o samosprávnych krajoch, http://www.vyvlastnenie.sk/predpisy/zakon-o-samospravnych-krajoch/ (20. 4. 2012). 
ZÁSTĚRA, K. (2001): Kulturní identita jihu USA. ISV, Praha, 147 pp.

ZEMÁNEK, L. (2003): Lokální kultura v životě našeho venkova. In: Jančák, V., Chromý, P., Marada, M. (eds): Geografie na cestách poznání. UK, PřF, KSGRR, Praha, pp. 124-149.

ZHANG, Y. (2001): Using the Internet for survey research: a case study. Journal of the American Society for Information Science, 5, No. 1, pp. 57-68.

ZICH, F. (2003): Regionální identita obyvatel Euroregionu Nisa. Regionální identita obyvatel v pohraničí. Sborník příspěvků z konference „Evropská, národní, či regionální identita?“. Praha 3. 10. 2003. Sociologický ústav Akademie věd ČR. pp. 17-59.

\section{Zhrnutie}

\section{SAMOSPRÁVNE REGIÓNY SLOVENSKA: PROSTOROVÁ DIFERENCIÁCIA A VNÍMANIE SOCIÁLNO-KULTURNEJ IDENTITY MISTNYCH A REGIONÁLNYCH ÚRADNÍKOV}

Cielom príspevku je pomocou vhodne zvolených otázok prezentovat miestnu a regionálnu identitu ako významný zdroj trvalo udržatelného národného bohatstva a taktiež účinný nástroj regionálneho rozvoja Slovenska. Jednotlivými otázkami sa snažíme identifikovat’ endogénny potenciál územia, aktivity, ktoré vedú $\mathrm{k}$ hrdosti byt' členom miestnej a regionálnej komunity. Uvedomenie si významu miestnej a regionálnej identity v regionálnom rozvoji pomáha miestnej komunite identifikovat' sa s miestom a lokálnym obyvatelstvom, ktoré je zodpovedné za sociálno-ekonomický rozvoj a zdravé životné prostredie v regióne. Udržovanie a zvelad’ovanie lokálnych tradícií a zvyklostí napomáha nielen k propagácii miestneho cestovného ruchu, ale taktiež generuje pocit štastia a sebavedomia obyvatelov.

Formuláciou jednotlivých otázok sa snažíme sledovat' tažiskové znaky regionálnej identity: výkonnost', tradíciu, komunikáciu, emociálne kompetencie a organizačné hodnoty. Každá obec, región má svoju históriu, tvár - genius loci; tieto hodnoty vytvárajú skutočnú identitu príslušného územia bojujúc proti každodennej uniformite a jednoliatosti.

Paasi (1986, 2001, 2003, 2004) tvrdí, že rozvoju regionálnych štruktúr v podobe kreovania sa inštitúcií predchádza fáza symbolického formovania regiónu. Hnacou silou procesu inštitucionalizácie je kultúrnohistorický a etnografický potenciál regiónu. Spolupatričnost’ obyvatelov na rôznych kultúrnych a sociálnych manifestáciách prispieva k formovaniu a zachovaniu pamäti a hrdosti obyvatelov $\mathrm{k}$ danému regiónu. Klúčovú úlohu pri samotnej inštitucionalizácii regiónu zohráva iniciatíva jednotlivcov, imidž regiónu (vnútorný a vonkajší), jeho názov a v neposlednom rade etablovanie inštitúcií, ktoré následne rozširujú povedomie a pozitívny imidž pomocou masmédií, regionálnej literatúry a vzdelávacieho systému. Tieto tvrdenia nám poslúžili ako inšpirácia pri formulovaní výskumných otázok.

Výber vzorky sme korigovali podla zákona č. 369/1990 Zb. o obecnom zriadení. Naš výberový súbor tvorili predstavitelia obecných a mestských zastupitel'stiev, starostovia obcí, primátori miest, zamestnanci obecných úradov a magistrátov miest, ktorí reprezentujú výkonné orgány miestnej samosprávy.

Z celkového počtu 10034 odoslaných emailov sa nám vrátilo 4326 elektronických ankiet. Našou snahou bolo zúžit' velkost' výberového súboru a modifikovat' ho pre potreby reprezentatívnosti. Z tohto dôvodu sme sa inšpirovali zámerným (kvótnym) výberom, kde sme na základe subjektívneho uváženia respondentov rozdelili proporcionálne podla podielu mestského a vidieckeho obyvatelstva, domácich a imigrantov v jednotlivých krajoch Slovenska na základe údajov z posledného cenzu obyvatel'stva (tab. 1). Pretože vzorka má byṫ reprezentatívna (má predstavovat' verný obraz populácie), určili sme po spracovaní jednotlivých ankiet kvótu 2114 respondentov. Jednou z možností aplikácie webového prieskumu môžu byt špecializované web stránky pre prípravu ankiet. V našom prieskume sme použili webový portál iankety.sk. Kedže sme využili jeho platenú verziu nedošlo $\mathrm{k}$ obtažovaniu respondentov počas vypíňania ankety rôznymi reklamami. Taktiež bola zabezpečená registrácia kontroly IP adries, ktorá umožnila spracovat' anketu maximálne raz z rovnakej IP adresy. Ďalšou výhodou tohto softvérového riešenia bola možnost' automatického zálohovania, priebežnej analýzy a hodnotenia výsledkov ankety v rôznych časových úsekoch počas realizácie internetovej sondy. Provider stránky 
nám poskytol server pre archiváciu a vyhodnotenie dát, t.j. priebežné, resp. celkové výsledky ankety sme mohli analyzovat’ a v Excely následne spracovávat'. Štatistika výsledkov a dáta respondentov boli dostupné v reálnom čase - v momente, ak prvý respondent vyplnil anketu. Takže sme mohli jednoducho sledovat stav ankety; skontrolovat', kto sa ešte nezúčastnil a opät mu zaslat' pozvánku. Respondent mohol odoslat iba kompletne vyplnenú anketu, tým sme minimalizovali možnost' registrácie neúplných odpovedí. Webová stránka iAnkety.sk nám poskytovala:

- zhrnút výsledky na otázky v ankete spolu s grafmi a percentuálnym rozdelením

- mať prehlad o respondentoch (údaje o každom účastníkovi)

- všetky odpovede respondentov modifikovat' (v Exceli)

- možnost' šírit’ výsledky pomocou špeciálneho odkazu.

Výhodou tohto postupu v porovnaní s telefonickým alebo osobným dopytovaním sú ušetrené náklady a neporovnatelne lacné a rýchle spracovanie dát, nakolko údaje sú už upravené v elektronickej forme (bližšie Zhang 2001; Cobanoglu, Warde, Moreo 2001). Respondentov sme následne oslovili prostredníctvom e-mailov, avšak využili sme aj sociálne siete a internetové portály, ktoré sú zamerané priamo na výskum verejnej mienky. Autori sú si vedomí aj nedostatkov, ktoré môžu vzniknút pri realizácií internetovej sondy:

- e-mailová pošta s odkazom na anketu môže skončit' v nevyžiadanej pošte (spame)

- výberový súbor respondentov, ktorý používa internet nemusí vykazovat totožné znaky správania sa s celkovou populáciou, t.j. vzniká problém reprezentatívnosti výskumu

- nie všetky vekové kategórie obyvatel'stva sa vyznačujú dostatočnými počítačovými vedomostami

- medzi nedostatky internetovej sondy môžeme zaradit’ aj technologické riešenia rôznych webových prehliadačov, ktoré nemusia podporovat softvérové požiadavky rozhrania ankety

- kedže realizácia internetovej sondy umožňuje respondentom samostatné rozhodovanie, pokyny pri jej vypĺn̆aní musia byt' vopred jasne a zrozumitelne definované.

Vzhladom na korektnost' metodologického prístupu a osloveným respondentom by sme v našej práci mohli hovorit’ skôr o (rozsiahlej) internetovej sonde realizovanej v jednotlivých krajoch Slovenska. Výsledky internetovej sondy nám dopomohli ku generalizácii a následnej interpretácii získaných poznatkov.

Pod lokálnymi elitami, ktoré tvoria výskumnú vzorku, rozumieme predstavitelov obecných a mestských zastupitel’stiev, starostov obcí, primátorov miest, zamestnancov obecných úradov a magistrátov miest. Nasledovne sme túto vzorku respondentov rozdelili na štyri základné kategórie: mestské a vidiecke obyvatel'stvo, rodákov a imigrantov. Uvedomujeme si možné dôsledky, ktoré vyplývajú z daného rozdelenia, napr. kategória mestského obyvatel'stva musí logicky obsahovat rodákov aj imigrantov žijúcich v danom meste, avšak vzhladom na stanovený ciel a charakter práce sme ponechali tieto kategórie respondentov v pôvodnom stave.

Prezentované odpovede boli transformované na jednotnú škálu pomocou normovanej premennej. Aplikáciou metódy hierarchickej zhlukovej analýzy sme definovali pät základných klastrov, ktoré sú explicitne vyjadrené v grafických prílohách (obrázkoch). Táto metóda vychádza z jednotlivých objektov, ktoré v prvom kroku reprezentujú zhluky. Použili sme metódu spájania, Single Linkage (Nearest Neighbour), tzv. jednoduché spájanie (najbližší sused). Vzdialenost medzi dvoma zhlukmi je definovaná ako vzdialenost' dvoch najbližších členov. Jednotlivé objekty sme spájali, pokial’ sme nedosiahli nami stanovený počet piatich zhlukov.

Fenomén kultúrnohistorickej pamäti prispieva $\mathrm{k}$ formovaniu teritoriálnej identity society regiónu. Kultúrnohistorická pamät (t.j. jej symbolická a duchovná dimenzia) reprezentuje entity prostredia, ktoré sú skupinovými identitami v spoločnosti vnímané prostredníctvom kultúrnych symbolov a antropogénnych artefaktov. Zmysel sociálnej a kultúrnohistorickej pamäti sa výraznejšie prejavuje na lokálnej i regionálnej úrovni. V tejto súvislosti môžeme hovorit’ o tzv. „sakralizácii“ historického priestoru miesta. Významné spomienky na historické udalosti regiónu aktivizujú kolektívne identity k prežívaniu uvedených epizód histórie lokality senzibilnejšie. Pod sakrálnostou historického priestoru miesta rozumieme každoročné pripomínanie si významných sviatkov, udalostí obce alebo lokality. Pamätný deň či sviatok v lokálnom spoločenstve symbolizuje renesanciu v zmysle znovuzrodenia kultúrnohistorickej pamäti.

Kultúrne dedičstvo a kultúrnohistorický potenciál slovenských regiónov sa nevyužíva efektívne vzhladom na možnosti, ktoré ponúka pre domáci a zahraničný kultúrny cestovný 
ruch. Medzi predstavitelmi miestnych elít nedošlo k jednotnému konsenzu ohladne spoločnej koncepcie, ktorá by vhodným spôsobom prezentovala kultúrny potenciál našich regiónov.

Vzhladom na rozmanité kvantitatívne výsledky obsiahnuté v grafoch a tabulkách, ktoré reprezentujú názory a postoje jednotlivých skupinových identít k nehmotným a hmotným prvkom kultúrneho dedičstva je vcelku komplikované dospiet’ ku kauzálnej a jednotnej priestorovej diferenciácii a percepcii sociálno-kultúrnej identity predstavitelmi miestnych elít. Prostredníctvom postojov respondentov $\mathrm{k}$ nehmotnému kultúrnemu dedičstvu ich miesta sme sa pokúsili zadefinovat vzt’ah medzi kultúrou - lokálnou identitou miesta - spoločnostou.

Obr. 1 -Klastre podla percentuálneho zastúpenia opýtaných, ktorí sú hrdí na krásy prírody vo svojom meste/vidieckej obci na Slovensku. Podiel pozitivnych odpovedí respondentov. Zdroj: databáza dotazníkového šetrenia.

Obr. 2 -Percentuálne zastúpenie respondentov, ktorí sú hrdí na históriu svojho mesta/ vidieckej obce na Slovensku.

Obr. 3 -Percentuálne zastúpenie respondentov, ktorí sú hrdí na zvyky a tradície svojho mesta/vidieckej obce na Slovensku.

Obr. 4 -Klastre podla percentuálneho zastúpenia opýtaných, ktorí sú hrdí na súčasnú ekonomickú situáciu v meste/vidieckej obci na Slovensku.

Obr. 5 -Klastre na základe percentuálneho zastúpenia kladných odpovedí respondentov na otázku „Áno, existuje obec/mesto, ktoré vnímam ako rodisko/rodný domov, a je totožné so súčasným bydliskom“.

Obr. 6 -Percentuálne zastúpenie respondentov, ktorí tvrdia, že v ich obci funguje folklórny súbor.

Obr. 7 -Klastre podla percentuálneho zastúpenia opýtaných, ktorí sú si vedomí, že v ich meste/vidieckej obci sídlia miestne, regionálne médiá.

Obr. 8 -Klastre podla percentuálneho zastúpenia opýtaných, ktorí sú si vedomí, že v ich meste/vidieckej obci sídlia inštitúcie, ktoré majú v názve regionálne symboly.

Obr. 9 -Percentuálne zastúpenie respondentov, ktorí sú si vedomí, že v ich meste/vidieckej obci prebiehajú počas roka oslavy regionálnych sviatkov, ktoré inde neexistujú.

Authors' affiliation: S. Bucher: Prešovská univerzita v Prešove, Fakulta humanitných a prírodných vied, katedra geografie a aplikovanej geoinformatiky, 17. Novembra 15, 08001 Prešov, Slovensko; e-mail: slavobucher@yahoo.com. M. Ištoková: Univerzita Karlova v Praze, Přirodovědecka fakulta, katedra socialni geografie a regionalniho rozvoje, Albertov 6, 12843 Praha 2, Česko; e-mail: miroslava.istokova@gmail.com.

Initial submission, 6 November 2013; final acceptance 14 November 2014.

\section{Please cite this article as:}

BUCHER, S., IŠTOKOVÁ, M. (2015): Self-Governing Regions in Slovakia: Spatial Differentiation and Perception of Socio-Cultural Identity by Local and Regional Officials. Geografie, 120, No. 1, pp. 1-25. 